JOURNAL OF GEOPHYSICAL RESEARCH, VOL. 90, NO. B7, PAGES 5371-5383, JUNE 10, 1985

\title{
MULTICOMPONENT MAGNETIZATIONS FROM THE MISSISSIPPIAN MAUCH CHUNK FORMATION OF THE CENTRAL APPALACHIANS AND THEIR TECTONIC IMPLICATIONS
}

\author{
Dennis V. Kent
}

Lamont-Doherty Geologica1 Observatory and Department of Geological Sciences, Columbia University, Palisades, New York

Neil D. Opdyke

Department of Geology, University of Florida, Gainesville

\begin{abstract}
Previous paleomagnetic study of Mississippian red beds of the Mauch Chunk Formation from the central Appalachians reported shallow inclination directions. A positive fold test was obtained after thermal demagnetization, typically to only $550^{\circ} \mathrm{C}$. The near-equatorial position for North America indicated by these results has been used to support the idea of a circa $15^{\circ}$ latitudinal tectonic offset of the Acadia displaced terrain in the northern Appalachians. The present study of 153 samples from 29 sites occupied in the Mauch Chunk Formation of eastern and southern Pennsylvania reveals mult icomponent magnetizations. A characteristic component (Declination $(D)=161.0^{\circ}$, Inclination $(I)=27.8^{\circ}$, a lpha 95 $(a 95)=7.9^{\circ}$ ) with unblocking temperatures usually
\end{abstract} concentrated above $650^{\circ} \mathrm{C}$ and with dual polarity (10 sites norma 1, 13 sites reversed) is isolated in 23 sites and passes a fold test at the $99 \%$ confidence level. It is interpreted as an early acquired hematitic (detrital or chemical) magnetization of pre-Alleghanian orogeny and preKiaman Reverse Polarity Interval age; a southern hemisphere paleolatitude of $15^{\circ}$ for the sampling area is indicated. Another component has generally lower unblocking temperatures which, however, can extend up to $650^{\circ} \mathrm{C}$ or more and therefore is also likely to be carried by hematite. This secondary magnetization ( $D=170.6^{\circ}$, $\mathrm{I}=-5.3^{\circ}$, a $95=5.0^{\circ}$ ) isolated in 25 sites is of uniform reverse polarity, and application of fold tests suggests that it is of synfolding origin; a near-equatorial paleolatitude $\left(3^{\circ} \mathrm{N}\right)$ at the time of acquisition is obtained, consistent with Permo-Carboniferous Kiaman directions from North America. Incomplete removal of the secondary component can explain the previous results from the Mauch Chunk. Comparison of the present paleomagnetic results with those from similar age rocks in the Canadian Maritimes does not support a latitudinal offset of Acadia with respect to interior North America in the Early Carboniferous. In fact, according to these and other paleomagnetic data thought to be representative of this age, the At lantic-bordering continents already were near to a Pangea configuration. The Alleghanian and particularly the Hercynian orogenies therefore may not be associated with the closure of a large (latitudina1) ocean later in the Carboniferous and Permian. Alleghanian deformation, however may have resulted in the partial bending of the Pennsylvanian salient on

Copyright 1985 by the American Geophysical Union.

Paper number 4B5100.

0148-0227/85/004B-5100\$05.00 the basis of apparently systematic deviations in paleomagnetic declinations.

\section{Introduction}

The paleomagnetic documentation of a displaced terrain is based on a comparison of paleopoles from it against a reference set from the stable craton of a continent. An apparent systematic discrepancy observed in Devonian and Early Carboniferous paleopoles for North America was used as evidence for the Acadia displaced terrain [Kent and Opdyke, 1978, 1979 ; Van der Voo et a 1., 1979]. The Acadia terrain encompasses the coasta 1 New England-Canadian Maritime region and is generally underlain by late Precambrian and early Paleozoic rocks with Avalonian affinities. The paleomagnetic data available were interpreted to show that the Acadia terrain translated approximately $15^{\circ}$ or $2000 \mathrm{~km}$ from more southerly latitudes to its present position relative to interior North America by the late Carboniferous which then was in more equatorial regions. The transcurrent movement was inferred to be of megatectonic significance, perhaps accommodated along large fault zones such as the Norumbega-

Fredericton in New Eng land and Canada and the Great Glen in Scotland [Van der Voo and Scotese, 1981]. However, there has been dispute regarding timing, magnitude, and sense of the transcurrent motion [Ludman, 1981; Harland, 1980; Bradley, 1982; Briden et al., 1984].

Critical to the concept of a latitudinal offset of Acadia is the reliability of inferred equatorial paleolatitudes obtained from Upper Devonian and Lower Carboniferous rocks from cratonic North America. At present, the key studies are on the Upper Devonian Catskili Formation [Van der Voo et al., 1979] and the Lower Carboniferous (Mississippian) Mauch Chunk Formation [Knowles and Opdyke, 1968], both of which report nearly identical paleolatitudes of about $4^{\circ}$ (in the southern hemisphere), norma 1 and reversed polarities, and positive fold tests. Roy and Morris [1983] have argued that both rock units may have been remagnetized in latest Pennsylvanianearliest Permian time, just prior to folding during a short interval of polarity changes within the Kiaman Reverse Interval. If so, the reported magnetization directions cannot be legitimately compared to what are presumed to be reliable Late Devonian and Early Carboniferous directions from the Canadian Maritime-coastal New England region (Acadia) for tectonic interpretation. We have resampled the Mauch Chunk Formation for paleomagnetic study to investigate more closely the possibility of remagnetization. 


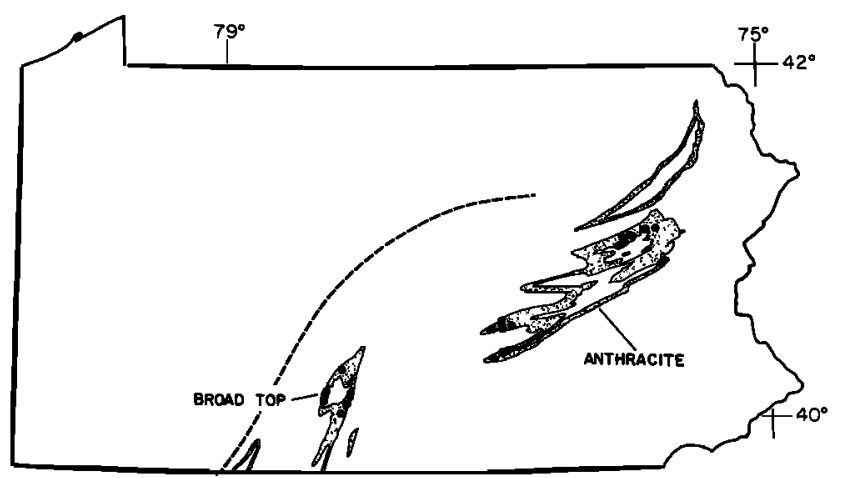

Fig. 1. Outcrop of Lower Carboniferous rocks (including the Mauch Chunk Formation) in the folded Appalachians of Pennsylvania, showing location of sites in the Broad Top and Anthracite sampling localities. Dashed line is trace of Alleghanian structural front.

\section{Geological Setting and Sampling}

The Mauch Chunk Formation consists of shales, siltstones, and sandstones, which are dominantly alluvial deposits red in color. In its upper part, it occasionally contains interbedded conglomerates. This red bed formation ranges up to over $1 \mathrm{~km}$ in thickness in eastern Pennsylvania, thins northwestward across strike, and correlatives extend southwestward toward Tennessee [Thomas, 1977]. In the anthracite coal basins of eastern Pennsylvania, with the local development of an intervening Meramecian limestone facies, the formation conformably overlies the Pocono Formation of earlier Mississippian age and is overlain by the lower Pennsylvanian Pottsville Formation with which it may intertongue in some areas [Wood et a1., 1969; Dennison, 1982]. In south central Pennsylvania, the Mauch Chunk overlies or intertongues with the fossiliferous Greenbrier Limestone, which extends into the Chesterian [Cooper, 1948; Dennison, 1982]. Thus the Mauch Chunk Formation is late Mississippian to perhaps earliest Pennsylvanian in age. It was folded in the Alleghanian orogeny whose climax is generally acknowledged to postdate the late Pennsylvanian to Early Permian Dunkard Group, the youngest sequence of $\mathrm{Paleozoic}$ strata in the Appalachian basin [Dennison, 1982].

Oriented samples were obtained in the field with a portable gasoline-powered drill. Twentynine sites, each represented by five or six independently oriented samples, were occupied and distributed over two general sampling localities, the Anthracite District in eastern and the Broad Top Basin in south central Pennsylvania (Figure 1). Bedding attitudes measured and recorded at each sampling site range in dip from nearly flat lying to vertical and in strike from NNE in the Broad Top area to ENE in the Anthracite area. Fresh outcrop was sought mostly in roadcuts, with a preference for the siltstone and finer-grained sandstone facies. Site locations and bedding strike and dip measured at each site are given in Table 1 .

\section{Paleomagnetic Results}

The intensity of the natural remanent magnetization (NRM) is typically of the order $10^{-2} \mathrm{~A} / \mathrm{m}$, similar to the values quoted by Knowles and Opdyke [1968] in their study. The site mean NRM directions also plot in the southeast quadrant, away from the present field direction. Progressive demagnetization was used to resolve the magnetization components that contribute to the NRM. Demagnetization behavior was analyzed on vector end point orthogonal projections, examples of which are shown in Figure 2 .

Aside from a minor low-temperature $\left(<300^{\circ} \mathrm{C}\right)$ but high stability to alternating fields (up to $100 \mathrm{mT}$ ) magnetization which tends to be aligned along the present field direction (e.g., samples $\mathrm{H} 2$ and $\mathrm{Zl}$ in Figure 2), the NRM can be accounted for by two components of magnetization. Most commonly observed is a low- to intermediatetemperature component with southerly declination and shallow inclination. This component is represented by a linear trajectory over demagnetization temperatures ranging from about $300^{\circ}$ to as high as $670^{\circ} \mathrm{C}$. The unblocking temperature spectrum is fairly uniform over this temperature range, a distributed component according to the terminology of Irving and 0pdyke [1965]. The high stability to alternatings fields and high unblocking temperatures suggest a hematite carrier.

TABLE 1. Site Locations and Bedding Attitudes

\begin{tabular}{|c|c|c|c|c|}
\hline \multirow[b]{2}{*}{ Site } & \multicolumn{2}{|c|}{ Location } & \multirow[b]{2}{*}{$\begin{array}{l}\text { Strike, } \\
\text { deg }\end{array}$} & \multirow[b]{2}{*}{$\begin{array}{c}\text { *Dip, } \\
\text { deg }\end{array}$} \\
\hline & $\begin{array}{c}\text { Lat itude, } \\
\mathbf{0}_{N}\end{array}$ & $\begin{array}{l}\text { Long itude, } \\
\mathrm{O}_{\mathrm{N}}\end{array}$ & & \\
\hline $\mathbf{A}$ & 41.06 & 75.86 & 233 & 06 \\
\hline B & 41.06 & 75.86 & 233 & 06 \\
\hline C & 41.03 & 75.96 & 254 & 02 \\
\hline D & 41.03 & 75.96 & 254 & 02 \\
\hline E & 41.04 & 75.78 & 218 & 07 \\
\hline $\mathbf{F}$ & 40.87 & 75.74 & 230 & 50 \\
\hline H & 40.56 & 76.96 & 152 & 16 \\
\hline I & 40.55 & 76.96 & 268 & 18 \\
\hline $\mathrm{J}$ & 40.56 & 76.97 & 071 & 71 \\
\hline $\mathbf{K}$ & 40.38 & 77.03 & 070 & 98 \\
\hline $\mathbf{L}$ & 40.36 & 77.02 & 070 & 86 \\
\hline M & 40.35 & 76.99 & 050 & 30 \\
\hline $\mathbf{N}$ & 40.54 & 77.01 & 300 & 36 \\
\hline 0 & 40.39 & 76.94 & 064 & 54 \\
\hline $\mathbf{P}$ & 40.40 & 76.91 & 058 & 61 \\
\hline$Q$ & 40.99 & 76.03 & 066 & 15 \\
\hline $\mathbf{R}$ & 40.99 & 76.02 & 075 & 15 \\
\hline s & 40.99 & 76.01 & 120 & 10 \\
\hline $\mathrm{T}$ & 41.03 & 76.02 & 262 & 14 \\
\hline $\mathbf{U}$ & 40.16 & 78.26 & 013 & 54 \\
\hline $\mathbf{v}$ & 40.16 & 78.26 & 017 & 52 \\
\hline$w$ & 40.16 & 78.26 & 022 & 49 \\
\hline $\mathrm{x}$ & 40.17 & 78.26 & 016 & 48 \\
\hline $\mathbf{Y}$ & 40.17 & 78.26 & 022 & 48 \\
\hline $\mathrm{z}$ & 40.93 & 78.13 & 208 & 07 \\
\hline $\mathbf{A A}$ & 40.13 & 78.10 & 209 & 12 \\
\hline BB & 40.14 & 78.08 & 208 & 17 \\
\hline $\mathrm{CC}$ & 40.16 & 78.08 & 214 & 13 \\
\hline DD & 40.31 & 78.15 & 019 & 16 \\
\hline
\end{tabular}

*Direction of bedding dip is $90^{\circ}$ clockwise from indicated bedding strike azimuth. 

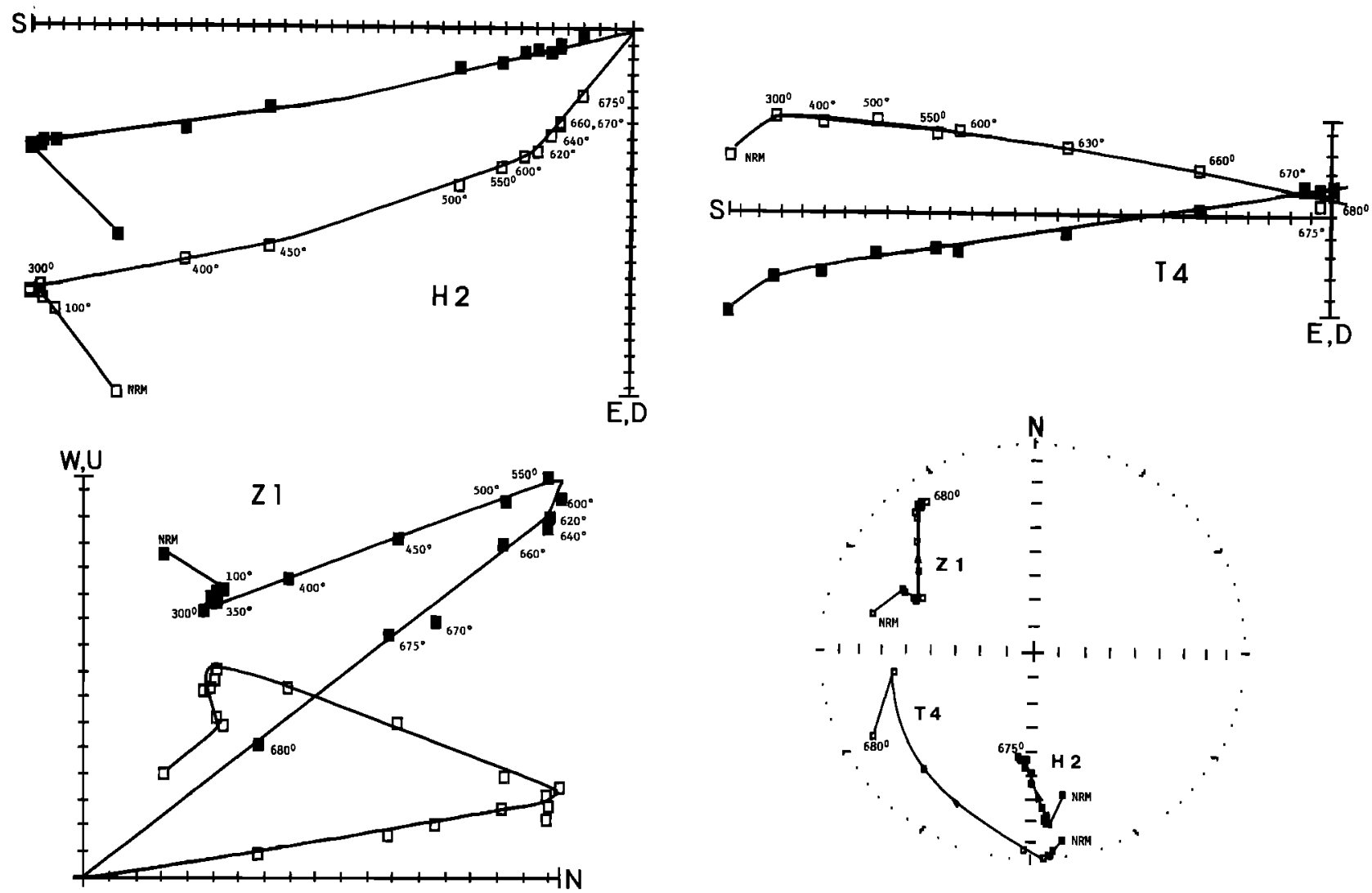

Fig. 2. Orthogonal projection diagrams of thermal demagnetization of NRM of representative Mauch Chunk samples. Open (solid) symbols depict projection of remanence vector end points on vertical (horizontal) planes in geographic coordinates. Magnetization units on axes in $10^{-2} \mathrm{~A} / \mathrm{m}$; treatment levels in degrees Celcius. Directions during progressive demagnetization of sample NRM plotted on equal-area projection in lower right.

The typically well-defined trajectory of the thermally distributed component does not usually trend toward the origin. Instead, a different, high unblocking temperature component is revealed with further demagnetization, typically over the $660^{\circ}-680^{\circ} \mathrm{C}$ range of treatments. Although present over a very confined demagnetization temperature interval, this thermally discrete magnetization component often constitutes an appreciable fraction of the NRM and in these cases is thus readily discerned in the vector diagrams. Both polarity states are represented by this magnetization between sites, with northerly upward and southerly downward directions (e.g., $\mathrm{Zl}$ and $\mathrm{H} 2$ in Figure 2).

All available samples were thermally demagnetized at a minimum of 10 temperature intervals, chosen on the basis of more detailed experiments on pilot samples from each site, to define the main magnetization components. The magnetization direction of each component (three or more colinear points) in each sample was calculated by the principal component method [Kirschvink, 1980] with the final high-temperature magnetization anchored to the origin.

\section{Analysis of Component Directions}

\section{High-Temperature Magnetization}

The discrete, high unblocking temperature component was successfully isolated in samples from 23 sites (Table 2). In samples from five sites (C, E, T, W, Y) a final component of magnetization is undoubted $1 y$ present since the demagnetization trajectory of the lower-temperature component typically does not converge to the origin (e.g., T4 in Figure 2). However, a final component could not be adequately resolved in samples at those 5 sites, apparently because it is of smaller relative magnitude and has a more over lapping unblocking temperature spectrum. Samples from site $P$ give curved or erratic trajectories, and no components could be isolated; this site was rejected in further analysis.

Although a dual-polarity distribution is apparent for the in situ site means (Figure 3 ), some directions deviate widely from the bipolar axis, and it is not immediately obvious to which polarity they should be assigned for statistical analysis. An estimate of the bipolar axis was therefore obtained initially from principal component analysis on the site means to allow an objective assignment of polarity. Site mean directions deviating more than $90^{\circ}$ from the orientation of one arbitrary end of this axis can then be inverted to allow application of Fisherian methods; 10 of the 23 site means were thus inverted to the common (southerly) hemisphere. The polarity of site $K$, with a mean direction almost exactly $90^{\circ}$ (within $1^{\circ}$ ) from the chosen axis direction, was included in the inverted set. Although more readily apparent by 
TABLE 2. Characteristic Site Mean Directions

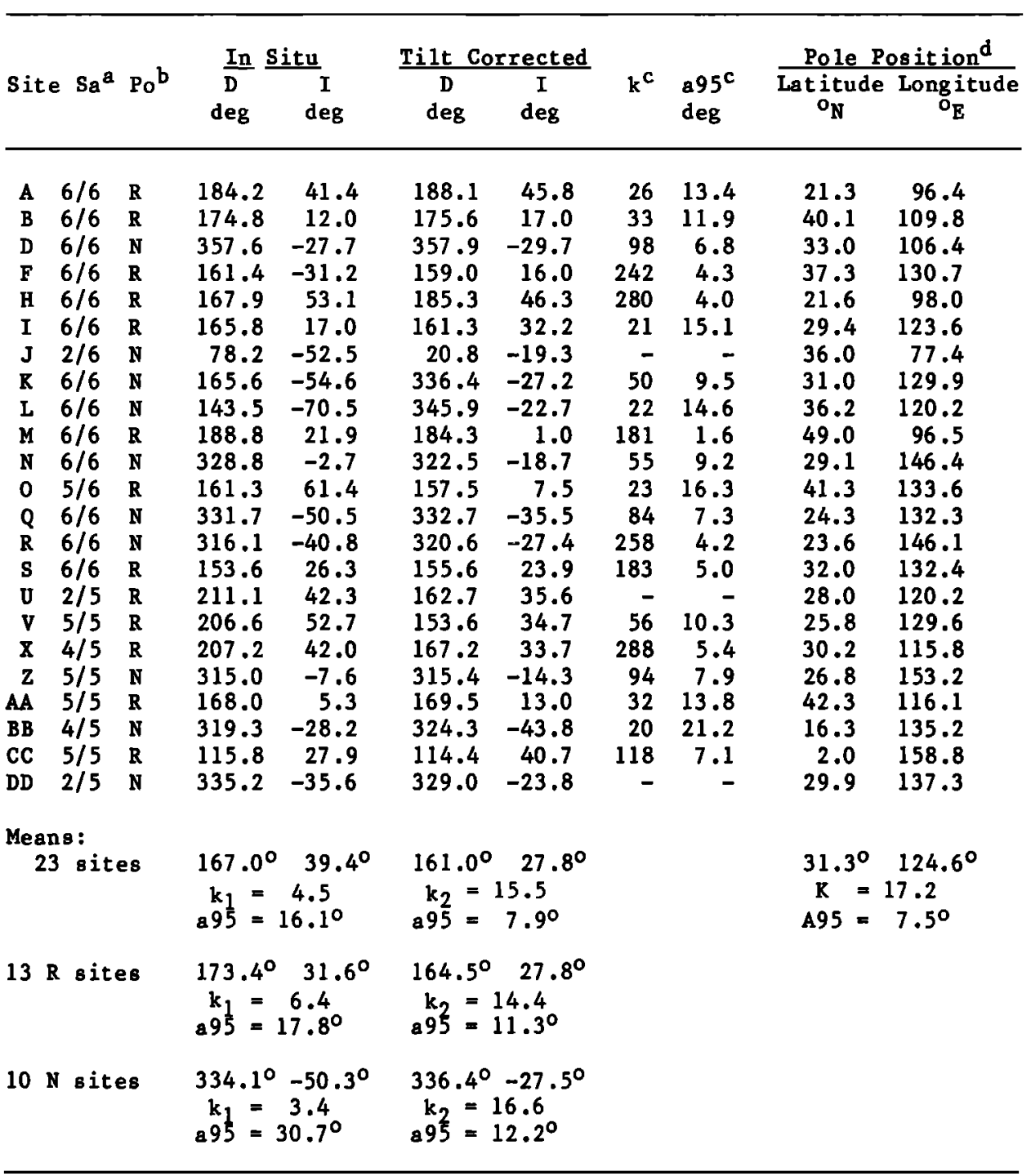

\footnotetext{
${ }^{a}$ Ratio of samples with acceptable data to samples measured.

Interpreted polarity of site magnetization, $N$ is normal, $R$ is reversed.

$c_{k}$ is best estimate of precision parameter and a95 is semiangle of the cone of $95 \%$ confidence [Fisher, 1953].

North pole position for tilt-corrected site means.
}

inspection, the required inversion of site means after tilt correction was done the same way, and it turns out that the same 10 site means need to be inverted.

The mean direction of the 23 site mean directions before bedding tilt correction is $D=167.0^{\circ}$, $I=39.4^{\circ}$, and the best estimate of the precision parameter, $k=4.5$. After tilt correction the mean is $D=161.0^{\circ}, I=27.8^{\circ}$ and $k=15.5$. F ratio criteria [McElhinny, 1964] indicate that the fold test is positive at the $99 \%$ confidence level and this component therefore can appropriately be referred to as the characteristic magnetization of the Mauch Chunk Formation. The arguments presented by McFadden and Jones [1981] regarding the conservative nature of McElhinny's test simply reinforce the level of significance of this positive fold test.
The northerly and southerly groups were analyzed separately, and their respective mean directions were compared to determine if they are coaxial. Either mean projected to opposite polarity falls within the circle of confidence associated with the other mean. Therefore the northerly and souther $1 y$ sets are considered antiparallel and not systematically contaminated by some noncoaxial magnetization. Moreover, for each polarity set a positive fold test is obtained (Table 2).

\section{Lower-Temperature Component}

The component with intermediate and widely distributed unblocking temperatures was successfully isolated in samples from 25 sites (Table 3). Site $P$ was again excluded for reasons 


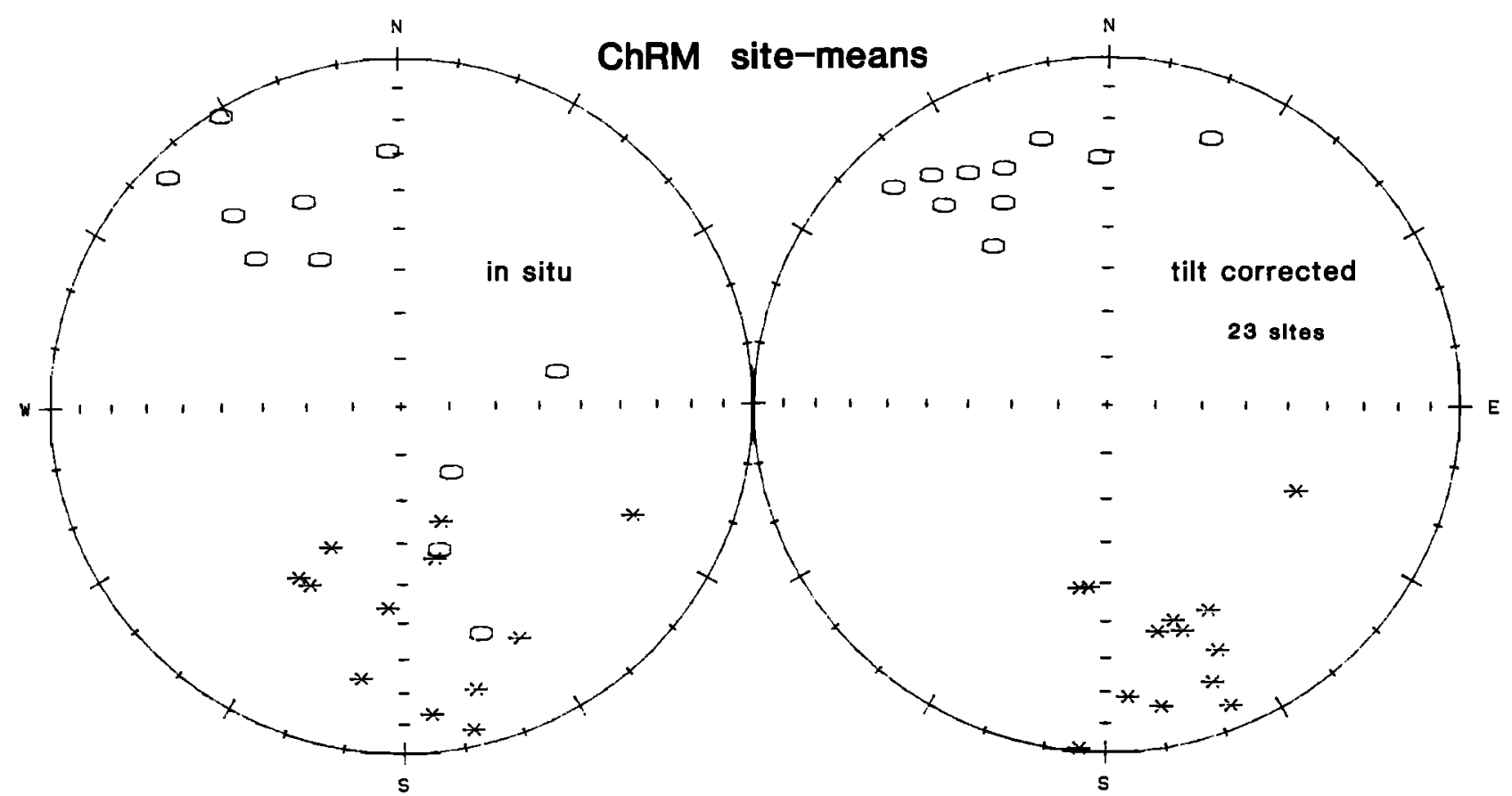

Fig. 3. Site mean directions of characteristic component of Mauch Chunk plotted before (left) and after (right) tectonic tilt corrections. Stars and open circles are plotted on lower and upper hemispheres, respectively, of equal-area projection.

stated previously. Although curvature in the demagnetization trajectories suggests its presence, an intermediate unblocking temperature magnetization could not be isolated in samples from site DD. The characteristic component also seriously interferes with the lower-temperature component at sites $K$ and $L$, resulting in imprecise estimates of the mean directions of the latter component (i.e., a95 values greater than $25^{\circ}$; Table 3 ) These sites are therefore excluded in further statistical analysis.

The lower-temperature component is of uniform polarity with a relatively shallow, southerly direction (Figure 4). Prior to tectonic tilt correction a mean direction of $\mathrm{D}=171.1^{\circ}, \mathrm{I}=-2.6^{\circ}$ $(k=21)$ is obtained for the 25 sites; after full tectonic tilt correction the mean is $D=171.6^{\circ}$, $I=-7.7^{\circ}(k=18)$, which is not significantly different in direction or dispersion. However, the change in the nature of the distribution of site means suggested that the rotation required to bring the beds at each site to the horizontal resulted in an overcorrection. We tested this possibility by calculating the mean and dispersion of the site means after each step of an incremental restoration of the tectonic tilts. The rotation at each step was a percentage of the measured bedding dip at each site, which was progressively increased until the beds were restored to the horizontal (i.e., full tectonic tilt correction). A11 25 sites were included in the analysis, even those associated with very small bedding tilts, so the test is considered to be conservative. The results are shown in Figures 4 and 5. Although the mean direction stays nearly the same, $k$ shows a systematic variation with progressive tilt corrections and peaks after the bedding tilts are restored about halfway. The increase in $k$ at $50 \%$ tilt correction is significant at $95 \%$ confidence compared to values of $k$ with no $(0 \%)$ or full (100\%) tilt correction; the corresponding mean direction is $\mathrm{D}=170.6^{\circ}, \mathrm{I}=-5.3^{\circ}, \mathrm{k}=35, \mathrm{a} 95=5.0^{\circ}$.

The significantly better grouping of the site means after only partial tilt correction implies that this lower unblocking temperature component is of synfolding, hence secondary origin. The same progressive tilt correction test on the characteristic magnetizations shows a monotonic increase in $k$ and a maximum value only after full tilt corrections (Figure 5), further supporting a prefolding origin for the characteristic magnetization. The different dispersion characteristics of the characteristic and secondary components also suggest that the change in $k$ with progressive tilt correction for the secondary component is not an artifact of strain history of the rocks in which both components reside.

\section{Comparison With Earlier Paleomagnetic Study of the Mauch Chunk Formation}

In an earlier paleomagnetic study of the Mauch Chunk, Knowles and Opdyke [1968] obtained a mean direction of $D=162^{\circ} \quad I=8^{\circ} \quad(k=28)$ after thermal demagnetization; the 20 acceptable site mean directions passed a fold test $(99 \%$ confidence leve1), and one of the sites gave normal polarity. These results were quite reasonably interpreted as a strong indication of a preAlleghanian orogeny, possibly primary, magnetization and accordingly widely used, implicitly or explicitly, to constrain the paleolatitudinal position of cratonic North America for tectonic interpretations [e.g., Kent and Opdyke, 1978, 1979; Kent, 1982; Van der Voo et a 1., 1979; Van der Voo, 1982, 1983; Irving, 1979; LeFort and Van der Voo, 1981; Van der Voo and Scotese, 1981; Perroud et al., 1984]. 
TABLE 3. Secondary Site Mean Directions

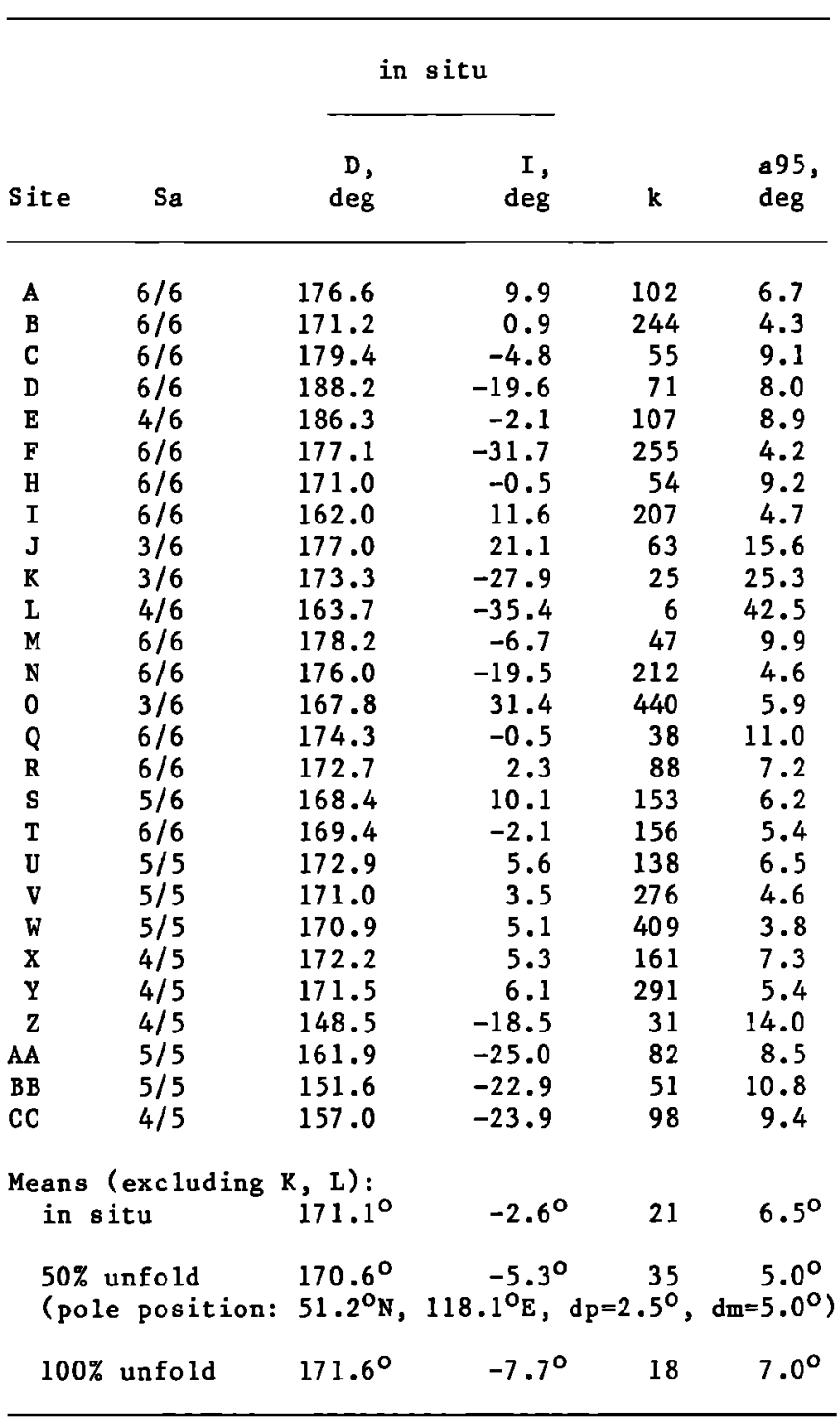

See Table 2 for explanation of parameters.

The characteristic mean direction obtained here on the Mauch Chunk is significantly different from, with an inclination $20^{\circ}$ steeper than, the direction obtained by knowles and 0pdyke. Yet the present results also pass the fold test ( $99 \%$ confidence level) and are represented by sites of opposite polarity, in this case 10 sites with northerly (normal) directions and 13 sites with southerly (reverse) directions that are statistically antipodal. The data of Knowles and Opdyke are dominated by sites with reverse polarity directions, but even if only the sites with reverse directions from the present study are compared with those in knowles and opdyke, the mean directions are still significantly steeper. Before broader interpretations of the present data are discussed, the lack of agreement between the basic conclusions of the two studies on the same rock unit needs to be addressed.

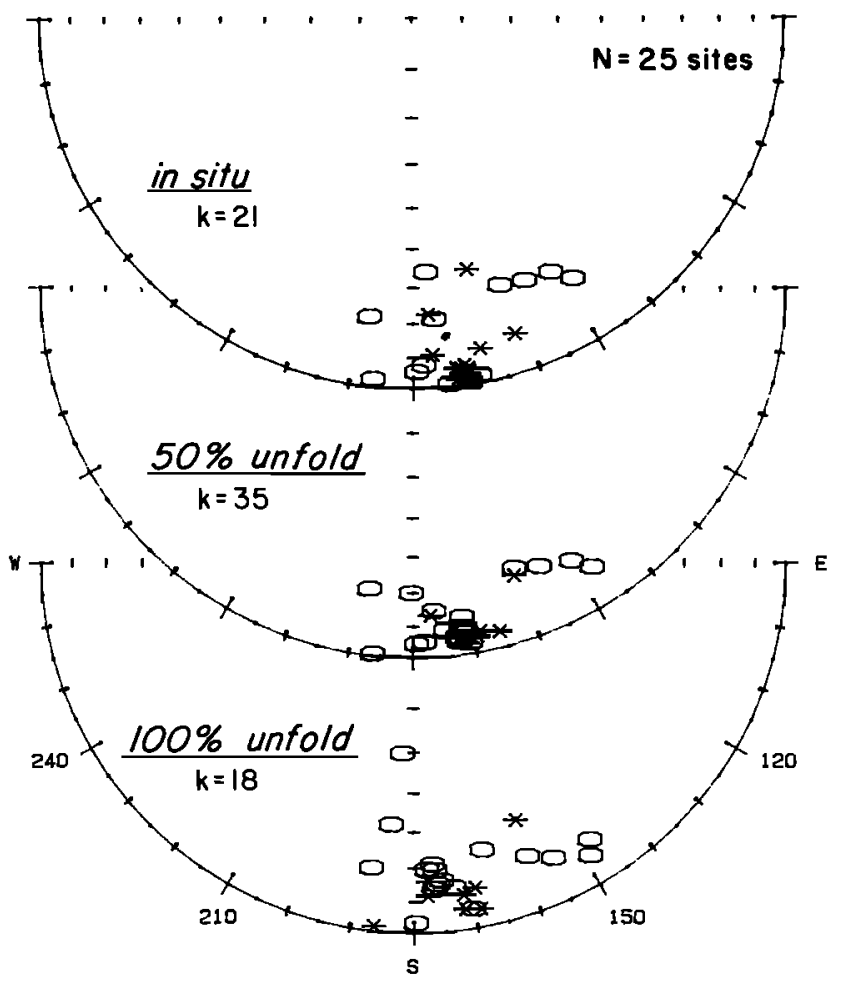

Fig. 4. Site mean directions of secondary component of Mauch Chunk, plotted before (top) and after $50 \%$ (middle) and full (bottom) tectonic tilt correction. Stars and open circles are plotted on lower and upper hemispheres, respectively, of equal-area projection.

In the study of Knowles and Opdyke [1968], selected samples were thermally demagnetized in steps up to only $550^{\circ}$ or $600^{\circ}$, and the site mean direction was calculated typically after thermal cleaning at $550^{\circ} \mathrm{C}$ (quoted range is $400^{\circ}-600^{\circ}$ ).

Figure 6 illustrates the geometrical relationship of the components of magnetization identified in

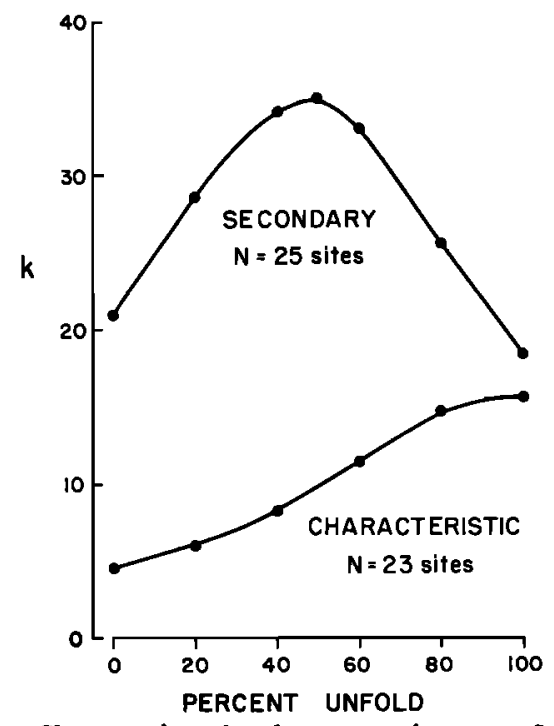

Fig. 5. Change in the best estimate of Fisher's precision parameter $k$ for the secondary component and the characteristic component site mean directions with progressive unfolding. 


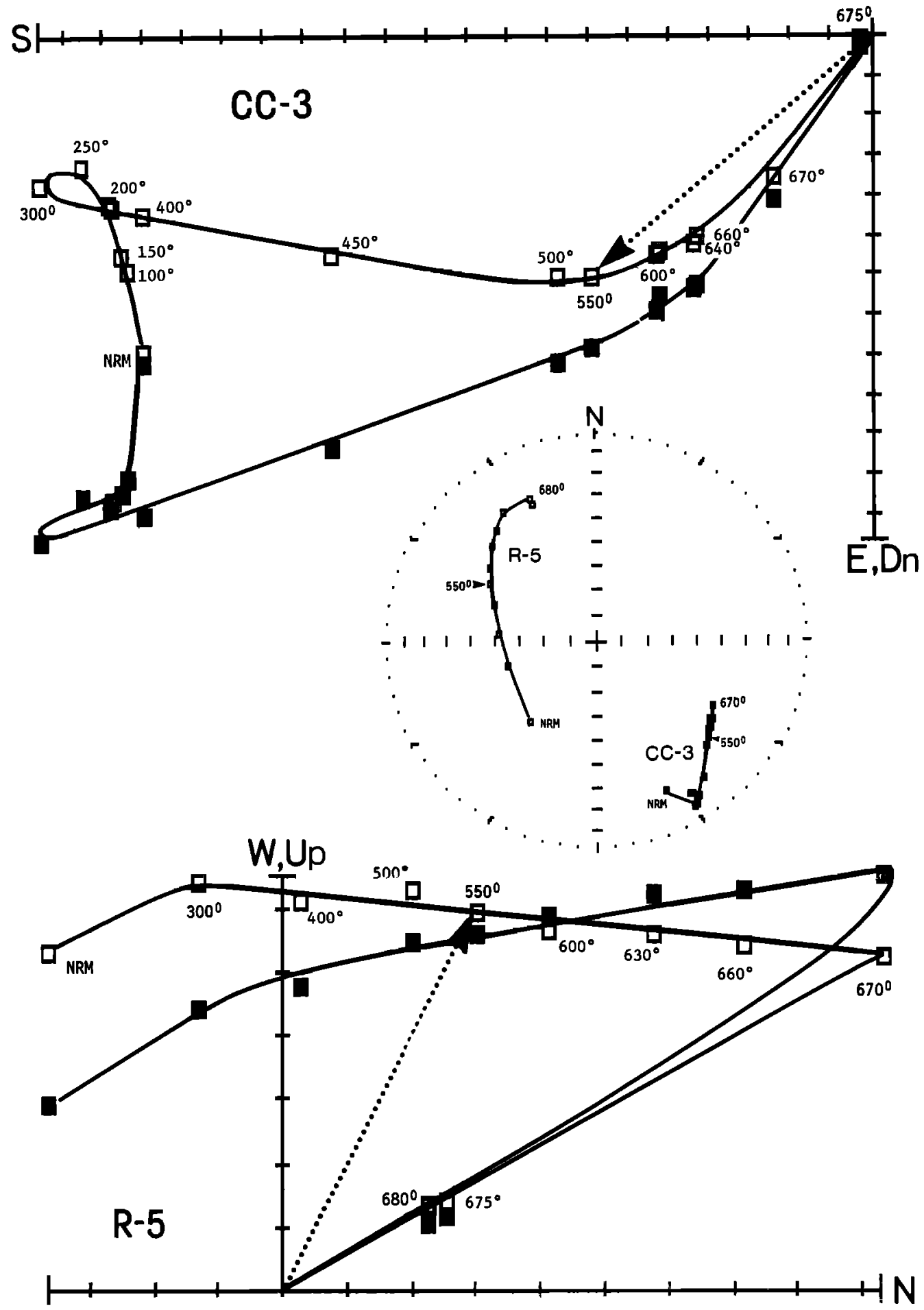

Fig. 6. Orthogonal projections (top and bottom) and equal-area projection (middle) of thermal demagnetization of NRM of two samples from Mauch Chunk Formation in bedding coordinates (see Figure 2 for plotting conventions). Dotted arrow (top and bottom) shows projection onto vertical plane of resultant vector after $550^{\circ}$ thermal demagnetization; corresponding directions are identified in equal-area projection (middle).

this study, and the magnetization obtained after $550^{\circ} \mathrm{C}$, in two representative samples. In the sample with a northerly characteristic direction ( $R 5$ in Figure 6) the $550^{\circ} \mathrm{C}$ magnetization has a steep, negative inclination. This situation may account for the steep, intermediate directions obtained at three sites that were rejected by
Knowles and Opdyke [1968] after similar temperature treatment. In the sample with a southerly characteristic direction, however, the $550^{\circ} \mathrm{C}$ magnetization is southerly and has an inclination that tends to be shallower than the characteristic inclination but steeper than the inclination of the secondary component (CC-3 in Figure 6). 


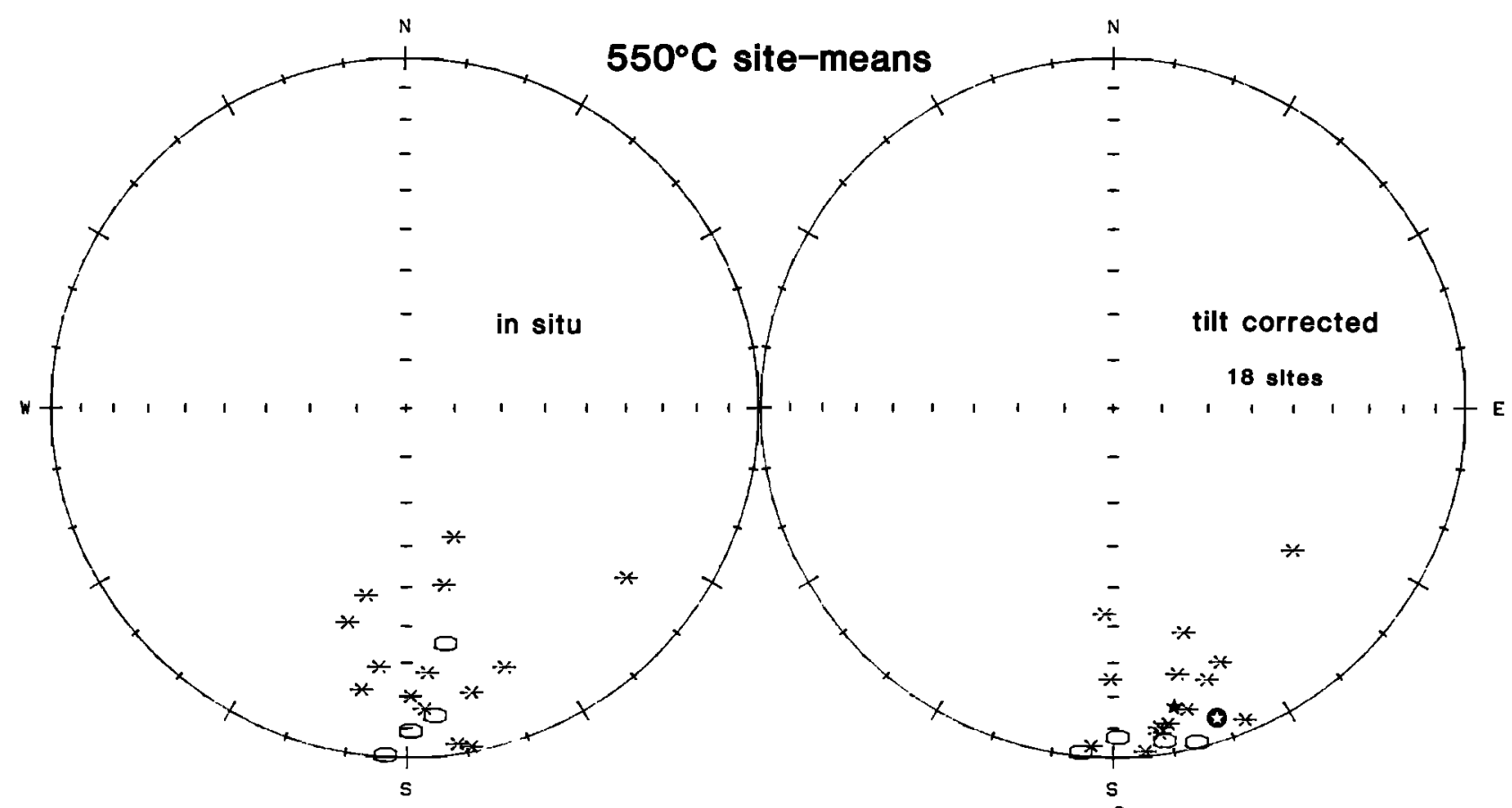

Fig. 7. Site mean directions of resultant magnetizations after $550^{\circ} \mathrm{C}$ thermal demagnetization plotted before (left) and after ( $r$ ight) tectonic tilt correction. Stars and open circles plotted on lower and upper hemispheres, respectively, of equal-area projection. Tilt corrected mean of these 18 site directions (solid star) and the mean direction for 20 sites in the Mauch Chunk Formation reported by Know les and Opdyke [1968] (circled star) are shown at right.

In other words, the $550^{\circ} \mathrm{C}$ magnetization is a resultant of the characteristic magnetization and some fraction of the secondary component.

The generality of this conclusion is demonstrated by the directional distribution of site means calculated after treatment to only $550^{\circ} \mathrm{C}$ (Figure 7). Included in the analysis are the 13 sites for which a southerly characteristic direction was isolated as well as the five sites where a characteristic direction was suspected but could not be resolved in our experiments. These 18 sites may be considered comparable to those that Knowles and Opdyke would have accepted for analysis; the 10 sites in the present study with northerly characteristic directions tend to give steep, intermediate directions at $550^{\circ} \mathrm{C}$ and are similarly excluded. Improvement in grouping of the 18 site means is apparent after tectonic tilt correction, with $k_{2} / k_{1}=1.95$, greater than the test value of 1.78 and therefore significant at the $95 \%$ confidence level according to the same conservative test of McElhinny [1964]. The mean for the 18 tilt-corrected site means ( $D=169.1^{\circ}$, $I=13.1^{\circ}$, a $\left.95=8.2^{\circ}\right)$ is, as expected, shallower than the characteristic direction, steeper than the secondary component direction, but similar (statistically indistinguishable) to the mean direction $\left(D=162^{\circ}, I=8^{\circ}\right.$, a $\left.95=6.3^{\circ}\right)$ reported by Know les and Opdyke [1968]. This agreement nicely accounts for the directions reported by Knowles and Opdyke [1968] as resultant magnetizations due to insufficient demagnetization. The $550^{\circ} \mathrm{C}$ directions pass the fold test because they include a sufficient contribution from the characteristic component that is demonstrated to be of prefolding origin, while the contribution to dispersion of the incompletely removed secon- dary component is nearly the same before and after full tilt correction.

\section{Interpretation of Present Paleomagnetic Results}

On the basis of the linear final demagnetization trajectories and the positive site mean reversal test, the Mauch Chunk characteristic magnetizations represent a sing le component of dual polarity. The formation is late Mississippian to earliest Pennsylvanian in age (approximately Visean-Namurian according to correlation chart of Van Eysinga [1978]) and was folded in the Alleghanian orogeny, nominally in the Late Carboniferous to Permian. The characteristic directions are shown to be of prefolding origin. According to analysis of paleomagnetic polarities in the Carboniferous Basin of Atlantic Canada, the stratigraphic horizon above which the predominantly reverse polarity Kiaman Interval is recorded occurs in the early Pennsylvanian (Namurian-Westphalian boundary [Roy and Morris, 1983]). The Mauch Chunk Formation is for the most part just older than this horizon, and about $40 \%$ of the sites have a normal polarity characteristic magnetization. Given these various constraints, we conclude that the characteristic magnetization represents a record of the paleomagnetic field close in age to deposition of the Mauch Chunk in approximately late Mississippianearliest Pennsylvanian (circa Visean-Namurian) time. The carrier of remanence is a phase of hematite which evidently preserves a detrital or early chemical remanent magnetization.

The overall average direction $\left(D=161.0^{\circ}\right.$, $\left.I=27.8^{\circ}\right)$ of the 23 tilt-corrected characteristic site means corresponds to a north paleopole posi- 


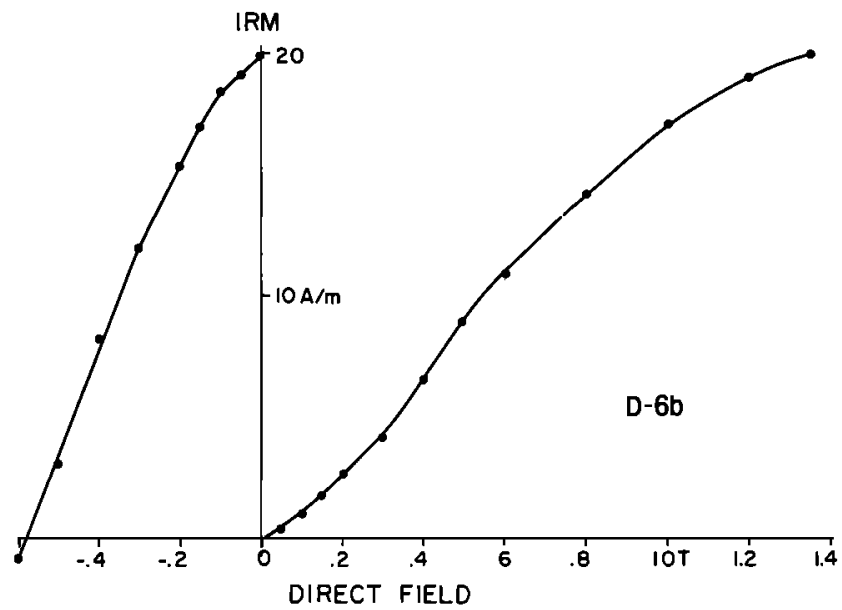

Fig. 8. Acquisition and backfield decay of isothermal remanent magnetization (IRM) in a sample of the Mauch Chunk Formation.

$t$ ion at $32.0^{\circ} \mathrm{N}, 124.8^{\circ} \mathrm{E}\left(\mathrm{dp}, \mathrm{dm}=4.7^{\circ}, 8.6^{\circ}\right)$ for a representative sampling location at $40.5^{\circ} \mathrm{N}$ $283^{\circ} \mathrm{E}$. Essentially the same paleomagnetic pole position $\left(31.3^{\circ} \mathrm{N}, 124.6^{\circ} \mathrm{E}, \mathrm{A} 95=7.5^{\circ}\right)$ is obtained by averaging site means converted to virtual geomagnetic poles to account for small differences in site locations. A mean paleolatitude of nearly $15^{\circ} \mathrm{S}$ is inferred for this area, which compares with a paleolatitude of on $1 \mathrm{y} 4^{\circ} \mathrm{S}$ obtained by Knowles and Opdyke [1968].

The secondary component of magnetization isolated in the present study of the Mauch Chunk was apparently acquired during Alleghanian folding and is consequently of Pennsylvanian (Late Carboniferous) to Permian age. The uniform southerly (reverse polarity) directions are consistent with acquisition during the post-Namurian to Late Permian Kaiman Interval of predominantly reverse polarity [Irving, 1966; Irving and Pullaiah, 1975; Roy and Morris, 1983]. The overall average direction $\left(D=170.6^{\circ} \quad I=-5.3^{\circ}\right)$ of the 25 site mean directions after $50 \%$ unfolding corresponds to a north paleopole position at $51.2^{\circ} \mathrm{N}, 118.1^{\circ} \mathrm{E}(\mathrm{dp}$, $\mathrm{dm}=2.5^{\circ}, 5.0^{\circ}$ ) and a paleolatitude of almost $3^{\circ} \mathrm{N}$. The paleomagnetic pole falls closest to the 250 $\mathrm{Ma}$ mean paleopole for North America $\left(49^{\circ} \mathrm{N}, 116^{\circ} \mathrm{E}\right)$ as determined by Irving and Irving [1982] using a $30 \mathrm{Ma}$ window.

Similar magnetization directions also apparently acquired during Alleghanian folding have been reported from Upper Silurian and Lower Devonian Helderberg strata from the central Appalachians [McCabe et al., 1983]. However, unlike those magnetite-bearing 1 imestones, no evidence for magnetite is evident in the bulk magnetic properties of the Mauch Chunk (Figure 8 ). The high coercivity of IRM, and the high stability to alternating fields and high unblocking temperatures of NRM instead point to hematite as the carrier of this secondary magnetization component. The broad range of unblocking temperatures of this component $\left(300^{\circ}\right.$ to more than $650^{\circ} \mathrm{C}$ ) probably reflects a wide distribution of grain sizes, but the mode of remanence acquisition is not clear. A viscous-thermal origin can be ruled out because exposure to an implausibly high acquisition temperature, even over a long time period, would seem to be required to account for the elevated laboratory unblocking temperature [Pullaiah et a1., 1975]. This secondary magnetization is more likely due to partial chemical remagnetization of the Mauch Chunk during folding, although deformation effects cannot be entirely excluded. Such secondary magnetizations are widespread in $\mathrm{Paleozoic}$ red beds from the Appalachians [Van der Voo, 1979].

Comparison With Paleopoles

From North American Carboniferous Rocks

Roy and Morris [1983] argued on the bas is of a concept of a Carboniferous geomagnetic polarity marker horizon that the dominantly reversed polarity directions obtained from Mississippian age rocks from interior North America (i.e., the Mauch Chunk Formation [Know les and Opdyke, 1968], the Barnett Formation of Texas [Kent and Opdyke, 1979], and the St. Joe Limestone of Arkansas [Scott, 1979] reflect remagnetization sometime during the Pennsylvanian to Permian Kiaman Reverse Polarity Interval. They conclude that there is no compeiling paleomagnetic evidence that the East Coast Basin (i.e., Acadia) had a separate tectonic history of movement in the Carboniferous. Irving and Strong [1984] more recent ly arrived at a similar conclusion from study of the Lower Carboniferous Deer Lake Group in western Newfoundland, which confirmed the paleomagnetic results on the Lower Carboniferous Barachois Formation reported by Opdyke [1981].

It is now clear that the directions reported by Knowles and Opdyke [1968] on the Mauch Chunk include resultant magnetizations and these results should not be used for tectonic interpretations. Instead, the dual polarity, characteristic magnetization for the Mauch Chunk isolated here is consistent with the Canadian Carboniferous paleomagnetic data. For example, the mean pole position of five Carboniferous results giving dual polarity (poles $R, E, S, M$, and $M S$ in Table 1 of Roy and Morris [1983]), is latitude $=34^{\circ} \mathrm{N}$, longitude $=119^{\circ} \mathrm{E}$, within the oval of confidence of the Mauch Chunk prefolding paleopole. Moreover, the disagreement of the revised Mauch Chunk characteristic direction with the Barnett and St. Joe paleomagnetic determinations is further evidence that these latter results are records of virtually complete remagnetization.

There remains an approximately $10^{\circ}$ difference in pole position (and predicted paleolatitude) between the Early Carboniferous of Newfoundland and that of the New Brunswick-Nova Scotia basin (together now with the Mauch Chunk from the foreland of the Appalachians). Presumably this will be shown to reflect a systemic age progression along the North American APWP as postulated by Irving and Strong [1984], rather than relative tectonic movements. Ironically, the $10^{\circ} \mathrm{dif}-$ ference between these Newfoundland and mainland North America Carboniferous paleopoles is in the same sense and of similar magnitude as previously postulated between Acadia and North America. The suggestion by Irving and Strong [1984] that the Mauch Chunk Formation, apparently on the basis of measurements on just two specimens [Irving and Opdyke, 1965], should typically yield steeper paleolatitudes consistent with those from the Deer Lake Group is not supported by the present study. Some of our characteristic sample and 


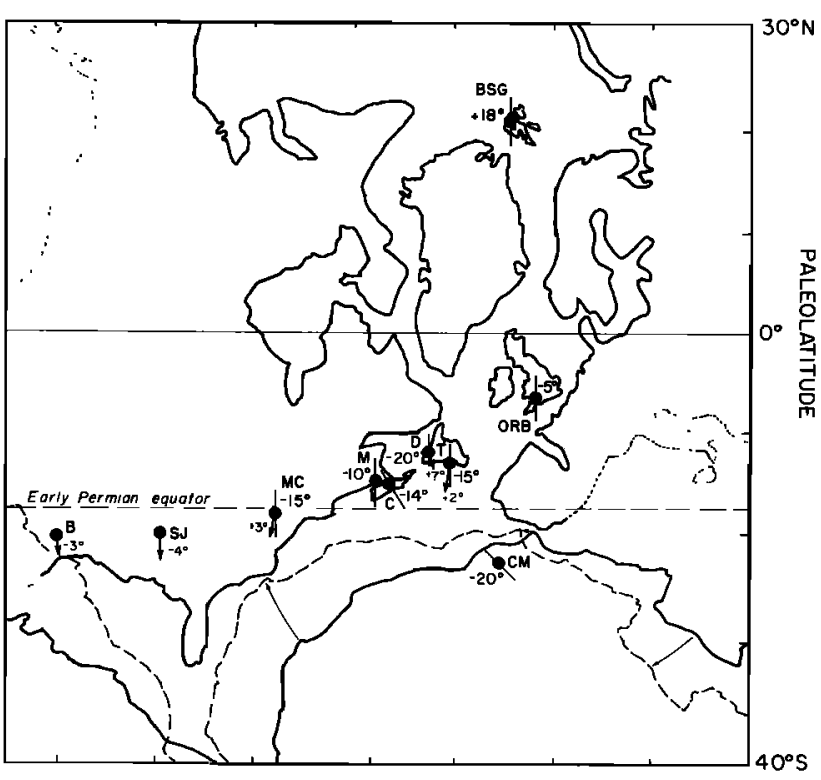

Fig. 9. Reconstruction of Atlantic-bordering continents constrained by paleomagnetic data. The fit of Euramerica is from Bullard et al. [1965], which is seen to satisfy Early Carboniferous paleomagnetic data, shown as orientation of paleomeridian and value of paleolatitude at sampling locality, from MC (Mauch Chunk, this study), $M$ (mean of poles $R, E, S, M$, and $M S$ in Table 1 of Roy and Morris [1983]); ORB (upper Old Red Sandstone, Bristol [Morris et al., 1973]), C (Cheverie Formation [Spariosu et al., 1984]), BSG (Billefjorden Sandstone Group [Watts, 1983]); T (Terrenceville [Kent, 1982]); and D (Deer Lake, [Irving and Strong, 1984]). Orientation of Africa-South America based on paleopole from Dwyka varves [McElhinny and Opdyke, 1968] and supported by paleolatitude determined from lower Carboniferous volcanics and sediments from Morocco (CM) [Martin et al., 1978]. Early Permian position of Africa-South America, corresponding to Pangea A2 configuration [Van der Voo et al., 1984], is shown by dashed continental outline and the paleoequator for this time is shown by dashed line. $\mathrm{Paleolatitude}$ determinationo from Lower Carboniferous Barnett Formation (B [Kent and Opdyke, 1979]) and St. Joe Limestone (SJ [Scott, 1979]) are now thought to reflect virtually complete remagnetization in the late Carboniferous or Permian and probably correlate with secondary components identified in $M C, D$, and $T$; these reverse polarity, secondary directions are denoted by arrows with their corresponding paleolatitudes in the smaller numerals.

even site mean directions (Table 2) do range as high irrespective of sign as the two values of inclination $\left(39^{\circ}\right.$ and $\left.42^{\circ}\right)$ they quote from Irving and Opdyke [1965], but the overall average we obtain for both normal and reverse polarity is about $10^{\circ}$ shallower than these. We also did not find any samples in our study of the Mauch Chunk that a lso have an "indisputed ly" sing le-component magnetization, although we did not sample exactly where Irving and Opdyke [1965] obtained their specimens.

In any case, it is an oversimplification to associate cratonic North American paleopoles that disagree with those from the New Brunswick-Nova Scotia Carboniferous basin, and which therefore may reflect remagnetization, with remanence that resides in hematite [Roy and Morris, 1983]. Remanent coercivity and unblocking temperature spectra of NRM and IRM were shown, for example, to be inconsistent with hematite but were compatible with magnetite, as the carrier of remanence in the calcareous concretions studied in the Barnett [Kent and Opdyke, 1979]. Nevertheless, limestones with similar magnetic properties to the Barnett, such as the Onondaga Formation [Kent, 1979], have been shown conclusively to be remagnetized on the basis of a negative fold test; such secondary magnetizations have been attributed in some cases to authigenic growth of magnetite [McCabe et al., 1983]. Indeed no single mechanism seems to be able to account for all the demonstrated or suspected remagnetizations when the different lithologies, magnetic mineralogies, and tectonostratigraphic settings of the affected rocks are considered. It nevertheless appears to us that there is in fact usually a good chance with thorough demagnetization to resolve an early acquired magnetization in a hematite-bearing red bed with multicomponent magnetization, as various recent studies, including the present one, show. In contrast drabcolored, magnetite-bearing limestones like the Barnett and the Onondaga tend to have univectorial magnetizations that tend to reflect virtually complete remagnetization by mechanisms still not very obvious.

\section{Tectonic Implications}

Figure 9 is an interpretation of paleocontinental positions for the At lantic-bordering continents in the Early Carboniferous that includes the results presented here. If the more southerly paleolatitudes obtained from Newfound land are attributed to an earlier paleofield, it is apparent that the bulk of Early Carboniferous paleomagnetic data do not require an offset in Euramerica, as suggested previously, and are in fact consistent with a conventional [Bullard et al., 1965] reconstruction of Euramerica. The European and Avalonian parts of Euramerica occupy similar paleolatitudes, as shown in various Late Devonian (and implied Early Carboniferous) reconstructions (e.g., Van der Voo, 1983]. It is the western part (Laurentia) that is now seen to be farther south than when positioned according to the Barnett, the St. Joe, and the previous Mauch Chunk paleomagnetic data.

Paleomagnetic data from Upper Devonian rocks can still be interpreted in terms of a latitudinal tectonic offset between Laurentia and northern Europe (plus Acadia) [e.g., Perroud et al., 1984]. However, although the critical study by Van der Voo et al. [1979] of the Catskill Formation that gives a near-equatorial paleolatitude involved vector analysis and is supported by a positive fold test, the reported lack of a late Paleozoic partial overprint in the Catskill is puzzling when such secondary components have been identified in most other middle Paleozoic red bed units from the Appalachians (e.g., Juniata Formation [Van der Voo et al., 1979], Bloomsburg Formation [Roy et a1., 1967], Mauch Chunk Formation (this study). Therefore unrecognized magnetiza- 
tion components may yet be present in the Catskill.

With regard to the position of Gondwana, the paleomagnetic data from the Dwyka varves of central Africa [McElhinny and Opdyke, 1968] place the northern margin of Africa into low paleolatitudes, about $20^{\circ} \mathrm{S}$. The Dwyka paleomagnetic results are supported by a positive fold test, but there is some uncertainty as to the age of the deposits. The Dwyka lies at the base of the Karoo System and in southernmost Africa is conventionally regarded as Late Carboniferous or Permian. McElhinny and 0pdyke [1968], however, favored an Early Carboniferous age for the Dwyka (at least in the sampling areas in Rhodesia, Zambia, and Tanzania), citing plant fossil evidence for a Late Devonian or Early Carboniferous assignment, the difference of the Dwyka paleopole from well-established Permo-Carboniferous poles from Gondwana, and the presence of normal polarities which are more compatible with a pre-Riaman (pre-Westphalian) time of magnetization. It might also be noted that the paleolatitude determined from paleomagnetic study of Lower Carboniferous basalts and sediments from Morocco [Martin et a 1., 1978] is consistent with Africa positioned according to the Dwyka paleopole (Figure 9).

Together these paleomagnetic results indicate that the width of any ocean separating Euramerica from the facing margins of Gondwana (Africa and South America) was likely to have been quite small by the Early Carboniferous. (There is even some evidence that the intervening ocean was already small in the Devonian, in the aftermath of the late Caledonian-Acadian orogeny [Kent et al., 1984]). Consequently, the AlleghanianHercynian orogeny which occurred later in the Carboniferous and Permian cannot be readily associated with the latitudinal closure of a large ocean. Although a few hundred kilometers of north-south shortening is not precluded, the paleomagnetic data are instead more compatible with a dominant tectonic framework of (dextral) shear for the Hercynian orogeny of Europe and of east-west shortening for the Alleghanian orogeny of the southern Appalachians as suggested by Arthaud and Matte [1977]. During this same time the entire Pangea assembly was also moving northward so that by the early Permian the paleoequator was located at about the present latitude of Pennsylvania and just of the reconstructed northern margin of Africa (Figure 9). As pointed out by Roy and Morris [1983] and Irving and Strong [1984], the reverse polarity magnetizations from the Barnett and the St. Joe, as well as the demonstrably secondary components in the Canadian Carboniferous rocks and now in the Mauch Chunk, all give nearly equatorial paleolatitudes. These directions are seen to agree well with the early Permian paleomagnetic field and most probably were acquired at about this time (Figure 9).

Finally, we address the question of bending of the folded Appalachians around the Pennsylvania salient with our revised paleomagnetic data from the Mauch Chunk Formation. Whereas Know les and Opdyke [1968] found virtually the same paleomagnetic directions from the Broad Top and Anthracite sampling areas, we now see a small, possibly significant difference. The characteristic site mean directions from the Anthracite area (sites A to $S$ in Table 2) give a positive ( $99 \%$ confidence) fold test and a tilt-corrected mean of $D=166.4^{\circ}$, $I=25.6^{\circ}$, a $95=9.7^{\circ}$. The eight characteristic site mean directions from the Broad Top area (sites $U$ to DD in Table 2) also give a positive ( $95 \%$ confidence) fold test but a tilt-corrected mean of $D=150.2^{\circ}, I=31.1^{\circ}$, a $95=13.5^{\circ}$. The Anthracite and Broad Top mean directions differ by $15.3^{\circ}$, mostly in the declinations, but the difference is not significant at the $95 \%$ confidence level according to the test of McFadden and Lowes [1981]. The same conclusion is reached comparing the averages of site mean virtual geomagnetic poles from both areas.

Taking the mean inclinations and declinations from each area separately, following Beck [1980], we are not surprised to find that the difference in inclination $\left(F=5.5^{\circ}\right)$ between the Broad Top and Anthracite areas is not significant (delta $\left.F=16.6^{\circ}\right)$. However, while the difference in declination $\left(R=16.2^{\circ}\right)$ is also not significant by conventional criteria (delta $R=19.1^{\circ}$ ) it does turn out to be significant according to the statistical method proposed by Demarest [1983] (corrected $95 \%$ confidence limit, delta $R=15.3^{\circ}$ ). A tentative interpretation of this difference in declination is that the Broad Top and Anthracite areas had rotated relative to each other in a sense that would account for approximately $25 \%$ of the present difference in structural trend around the Pennsylvania salient. However, the difference between the Anthracite and Broad Top characteristic directions thus far obtained must be regarded as statistically marginal, and we defer further discussion of tectonic implications pending acquisition of more definitive data.

Acknowledgments. The assistance of C. Kent and $A$. Rent in the fieldwork, the laboratory work of D. Lafferty, and the critical reading of the manuscript by B.M. Clement and T. Engelder are appreciated. This work was supported by the National Science Foundation, Earth Sciences grant EAR82-12549 (D.V.K.). Lamont-Doherty Geological Observatory contribution 3799.

\section{References}

Arthaud, F., and P. Matte, Late Paleozoic strikeslip faulting in southern Europe and northern Africa: Result of a right-lateral shear zone between the Appalachians and the Urals, Geol. Soc. Amer. Bu I1, 88, 1305-1320, 1977.

Beck, M. E., Paleomagnetic record of plate-margin tectonic processes along the western edge of North America, J, Geophys. Res., 85, 71157131,1980 .

Bradley, D. C., Subsidence in late Paleozoic basins in the northern Appalachians, Tectonics, $1,107-123,1982$.

Briden, J. C., H. B. Turne11, and D. R. Watts, British paleomagnetism, Iapetus Ocean and the Great Glen Fault, Geology, 12, 428-431, 1984.

Bullard, E. C., J. E. Everett, and A. G. Smith, A symposium on continental drift, IV, The fit of the continents around the At lantic, Philos. Trans. R. Soc. London, Ser. A., A258, 41-51, 1965.

Cooper, B. N., Status of Mississippian stratigraphy in the central and northern Appalachian region, J. Geo1. 느, 255-263, 1948. 
Demarest, H. H. Jr., Error analys is for the determination of tectonic rotation from paleomagnetic data, J. Geophys. Res., 88, 43214328,1983 .

Dennison, J. M., Uranium favorability of nonmarine and marginal-marine strata of Late Precambrian and Paleozoic age in Ohio, Pennsylvania, New Jersey, and New York, Nat. Uranium Resour. Eva 1. Rep. GJBX-50(82) 254 pp., Grand Junct ion, Colorado, 1982.

Fisher, R.A., Dispersion on a sphere, Proc. R. Soc. London, Ser. A., 217, 295-305, 1953.

Harland, W. B., Comment and reply on "A paleomagnetic pole position from the folded Upper Devonian Catskill red beds, and its tectonic implications," Geology, 8, 258-259, 1980.

Irving, E., Paleomagnetism of some Carboniferous rocks from New South Wales and its relation to geological events, J. Geophys, Res., 71, 6025$6051,1966$.

Irving, E., Paleopoles and paleolatitudes of North America and speculations about displaced terrains, Can. J. Earth Sci. 16, 669-694, 1979.

Irving, E., and G. A. Irving, Apparent polar wander paths Carboniferous through Cenozoic and the sssembly of Gondwana, Geophys. Surv., 5, 141-188.

Irving, E., and N. D. Opdyke, The paleomagnetism of the Bloomsburg red beds and its possible application to the tectonic history of the Appalachians, Geophys. J. R. Astron. Soc., 9 , $153-166,1984$.

Irving, E., and G. Pullaiah, Reversals of the geomagnetic field, magnetostratigraphy, and relative magnitude of paleosecular variation in the Phanerozoic, Earth Sci. Rev. 12, 35-64, 1976.

Irving, E., and D. F. Strong, Paleomagnetism of the Early Carboniferous Deer Lake Group, western Newfoundland: No evidence for Carboniferous displacement of "Acadia," Earth Planet. Sci. Lett. 69, 379-390, 1984.

Kent, D. V., Paleomagnetism of the Devonian Onondaga limestone revisited, J. Geophys. Res. 84, 3576-3588, 1979.

Kent, D. V., Paleomagnetic evidence for postDevonian displacement of the Avalon Platform (Newfound land), J. Geophys. Res., 87, 8709$8716,1982$.

Kent, D.V., and N. D. Opdyke, Paleomagnetism of the Devonian Catskill red beds: Evidence for motion of coastal New England-Canadian maritime region relative to cratonic North America, J. Geophys. Res.. 83, 4441-4450, 1978.

Kent, D. V., and N. D. Opdyke, The Early Carboniferous paleomagnetic field of North America and its bearing on teconics of the northern Appalachians, Earth Planet. Sci. Lett. 44 365-372, 1979.

Kent, D. V., O. Dia, and J. M. A. Sougy, Paleomagnetism of Lower-Middle Devonian and upper Proterozoic-Cambrian(?) rocks from Mejeria (Mauritania, West africa), in Plate Reconstruction From Paleozoic Paleomagnetism, Geodyn. Ser. vo1. 12, edited by R. Van der Voo, C. R. Scotese, and N. Bonhommet, pp. 99-115, AGU, Washington, D.C., 1984 .

Kirschvink, J. L., The least-squares $l i n e$ and plane and the analysis of palaeomagnetic data, Geophys. J. R. Astron. Soc., 62, 699-718, 1980 .

Knowles, R. R., and N. D. Opdyke, Paleomagnet ic results from the Mauch Chunk Formation: A test of the origin of curvature in the folded Appalachians of Pennsylvania, J. Geophys. Res. 73, 6515-6526, 1968.

LeFort, J.-P., and R. Van der Voo, A kinematic model for the collision and complete suturing between Gondwanaland and Laurussia in the Carboniferous, J. Geol. 89, 537-550, 1981.

Ludman, A., Significance of transcurrent faulting in eastern Maine and location of the suture between Avalonia and North America, Am. J. Sci. 281, 463-483, 1981 .

Martin, D. L., A. E. M. Nairn, H. C. Noltimier, M. H. Petty and T. J. Schmitt, $\mathrm{Paleozoic}$ and Mesozoic paleomagnetic result a from Morocco, Tectonophysics, 44, 91-114, 1978.

McCabe, C., R. Van der Voo, D. R. Peacor, C. R. Scotese and R. Freeman, Diagenetic magnetite carries ancient yet secondary remanence in some Paleozoic sedimentary carbonates, Geology, 11, 221-223, 1983.

McElhinny, M. W., Statistical significance of the fold test in palaeomagnetism, Geophys, J, R. Astron, Soc. 8, 338-340, 1964 .

McElhinny, M. W., and N. D. Opdyke, Paleomagnetism of some Carboniferous glacial varves from Central Africa, J. Geophys, Res., 73 , 689-696, 1968.

McFadden, P. L., and D. L. Jones, The fold test in palaeomagnetism, Geophys. J. R. Astr. Soc. $67,53-58,1981$.

McFadden, P. L., and F. J. Lowes, The discrimination of mean directions drawn from Fisher distributions, Geophys, J. R. Astr. Soc., 67, 19-33, 1981.

Morris, W. A., J. C. Briden, J. D. A Piper, and J. T. Sallomy, Paleomagnetic studies in the British Caledonides, $\nabla$, Migcellaneous new data, Geophys. J. R. Astron. Soc. 34, 69-105, 1973 .

Opdyke, N. D., Paleomagnetism of the Barachois Fm. and the extent of the Acadian displaced terrane (abstract), Eos Trans, AGU, 62, 264, 1981.

Perroud, H., R. Van der Voo, and N. Bonhommet, Paleozoic evolution of the Armorica plate on the basio of paleomagnetic data, Geology 12 , $579-582,1984$.

Pullaiah, G., E. Irving, K. L. Buchan, and D. J. Dun lop, Magnetization changes caused by burial and uplift, Earth Planet. Sci. Lett. 28, 133$143,1975$.

Roy, J. L., and W. A. Morris, A review of paleomagnetic results from the Carboniferous of North America: The concept of Carboniferous geomagnetic field horizon markers, Earth Planet. Sci. Lett., 65, 167-181, 1983.

Roy, J. L., N. D. Opdyke, and E. Irving, Further paleomagnetic results from the Bloomsburg formation, J. Geophys. Res., 72, 5075-5086, 1967.

Scott, G. R., Paleomagnetic studies of the Early Carboniferous St. Joe limestone, Arkansas, J. Geophys. Res., 84, 6277-6285, 1979.

Spariosu, D. J., D. V. Kent, and J. D. Keppie, Late Paleozoic motions of the Meguma terrane, Nova Scotia: New paleomagnetic evidence, in Plate Reconstruction From Paleozoic Paleomagnet ism, Geodyn. Ser, vol. 12, edited by R. Van der Voo, C. R. Scotese, and N. Bonhommet, Pp. 82-98, AGU, Washington, D.C., 1984.

Thomas, W. A., Evolution of Appalachian-Ouachita 
salients and recesses from reentrants and promontories in the continental margin, Am. $\mathrm{J}_{\text {. }}$ Sci. 277, 1233-1278, 1977 .

Van der Voo, R., Age of the Alleghenian folding in the central Appalachians, Geology, I, 297$298,1979$.

Van der Voo., R., Pre-Mesozoic paleomagnetism and plate tectonics, Annu. Rev. Earth Planet. Sci. 10, 191-220,1982.

Van der Voo., R., Paleomagnetic constraints on the assembly of the 01d Red Continent, Tectonophysics, 91, 271-283, 1983.

Van der Voo, R., and C. Scotese, Paleomagnetic evidence for a large $(2,000 \mathrm{~km})$ sinistral offset along the Great Glen fault during Carboniferous time, Geology, 9, 583-589, 1981.

Van der Voo, R., A. N. French and R. B. French, A paleomagnetic pole position from the folded Upper Devonian Catskill redbeds, and its tectonic implications, Geology, 7, 345-348, 1979.

Van der voo, R., J. Peinado, and C. R. Scotese, A paleomagnetic reevaluation of Pangea reconstructions, in Plate Reconstruction from Paleozoic Paleomagnetism, Geodyn. Ser., vol.
12, edited by R. Van der Voo, C. R. Scotese and N. Bonhommet, pp. 11-26, AGU, Washington, $D$. C., 1984.

Van Eysinga, F. W. B. (Compiler), Geological Time Table, 3 rd ed., Elsevier, Amsterdam, 1978.

Watts, D. R., Further Lower Carboniferous paleomagnetic results from the Billefjorden region of Spitzbergen, Eos Trans, AGU, 64, 216, 1983.

Wood, G. H., Jr., J. P., Trexler and T. M. Kehn, Geology of the west-central part of the southern anthracite field and adjoining Pennsylvania, U.S. Geo1. Surv, Prof. Pap., 602, 150 pp., 1969.

D. V. Kent, Lamont-Doherty Geological Observatory, Palisades, NY 10964.

N. D. Opdyke, Department of Geology, Univer sity of Florida, Gainesville, FL 32611.

(Received April 30. 1984;

revised December 3, 1984; accepted January 15, 1985.) 